\title{
STRUCTURAL-DYNAMIC PECULIARITIES OF PHYTOCOENOSES OF AN INTERZONAL ECOTONE IN SOUTH-WESTERN TRANS-BAIKAL (Surroundings of Lake Gusinoe, Buryat Republic, Russia)
}

\begin{abstract}
Alexander Sizykh
Siberian Institute of Plants Physiology and Biochemistry of RAS SB, 664044, Irkutsk, 132 Lermontova str., Russia;

Corresponding author Alexander Sizykh, e-mail: alexander.sizykh@gmail.com;
\end{abstract}

Received December 2019; Accepted January 2020; Published February 2020;

DOI: https://doi.org/10.31407/ijees10.123

\begin{abstract}
The phytocoenoses of environments contact in the Pre-Baikal reflect modern trends of formation and development of vegetation on the territories under concrete hysic-geographycal conditions in the different areas of Baikal region at all. The Selenga R. Basin, including surroundings of Lake Gusinoe, is within most important biogeographic boundaries, ones of areas and proivinces of southern boreal forests and zonal dry bunch-cereals Central Asian steppes, where zona forest-steppe is formed, the processes of environment degradation are more considerably expressed.
\end{abstract}

Key words: phytocoenoses, forest-steppe zone, interzonal ecoton, the South-Western Trans-Baikal 